\title{
Optimalisasi Citra Axial Sequence T2 Gradient Echo Dengan Variasi Bandwidth Dan Time Echo Pada MRI Shoulder Untuk Mengurangi Susceptibility Artifacts Dan Chemical Shift
}

Akhmad Muzamil ${ }^{{ }^{*}}$, Nur Vita Indri ${ }^{2}$, Suryani Dyah Astuti ${ }^{2}$, Tri Anggono Prijo ${ }^{2}$

\section{Intisari}

Penelitian ini bertujuan untuk mengetahui pengaruh Bandwidth (BW) dan Time Echo (TE) pada MRI Shoulder serta mengetahui nilai variasi Bandwidth dan Time Echo yang optimal untuk mengurangi Susceptibility Artifacts dan Chemical Shift. Penelitian ini di lakukan di Rumah Sakit Umum Haji Surabaya dengan menggunakan Pesawat MRI 1,5 Tesla. Penelitian ini menggunakan varaisi Bandwidth $170 \mathrm{~Hz} / \mathrm{Px}$, $190 \mathrm{~Hz} /$ Px dan $210 \mathrm{~Hz} /$ Px serta menggunakan variasi TE 16 ms dan 20 ms pada pembobotan T2 Medic potongan axial terhadap 4 pasien. Analisa data dilakukan secara kuantitatif dengan menggunakan metode Region of Interest (ROI) pada komputer MRI kemudian dilakukan analisis Signal to Noise Ratio (SNR) dan Contrast to Noise Ratio (CNR) serta analisis terhadap Susceptibility Artifacts dan Chemical Shift. Variasi Time Echo dan bandwidth berpengaruh signifikan terhadap nilai SNR dan CNR pada hasil citra T2 Axial Gradient Echo MRI Shoulder. Pengaruh kedua variasi tersebut adalah semakin kecil nilai TE dan BW didapatkan SNR yang meningkat. Jika TE diperbesar maka didapatkan CNR yang meningkat. Kualitas citra optimal yang dapat menghasilkan keadaan patologis ditentukan dengan meningkatnya nilai CNR dan nilai artefak yang menurun. Sehingga pada penelitian ini kombinasi antara 2 variabel tersebut dapat menentukan citra optimal pada TE 20ms dan BW $210 \mathrm{~Hz} / \mathrm{Px}$.

Keywords: Bandwidth, TE, T2 Medic, MRI Shoulder

\section{Pendahuluan}

Radiodiagnostik merupakan cabang radiologi yang bertujuan untuk mendiagnosis adanya suatu kelainan (patologi) dalam tubuh pasien. Alat-alat radiodiagnostik yang digunakan antara lain X-Ray, CT-Scan, dan MRI. X-Ray dan CT-Scan menggunakan radiasi sinar- $X$ dalam mendiagnosis suatu

Afiliasi Penulis

1 | Pasca Sarjana TeknoBiomedik, Universitas Airlangga.

2 | Departemen Fisika, Fakultas Sains dan Teknologi, Universitas Airlangga

Korespondensi kepada

A. Muzamil

muzamilakhmad@gmail.com kelainan dalam tubuh pasien sehingga memungkinkan adanya radiasi ionisasi pada jaringan yang sehat. Magnetic Resonance Imaging (MRI) merupakan alat radiodiagnostik yang berfungsi untuk menghasilkan rekaman potongan gambar penampang tubuh manusia dengan menerapkan prinsip resonansi magnetik proton atom hidrogen dengan medan magnet eksternal dan frekuensi radio (RF). Pemanfaatan medan magnet dan gelombang radio frekensi untuk menghasilkan suatu gambar lebih aman digunakan karena tidak menggunakan sinar- $X$ yang menyebabkan radiasi ionisasi yang berbahaya [1]

MRI mempunyai kelebihan di antaranya ialah memberikan gambaran jaringan lunak yang sangat jelas dibandingkan dengan alat penegakan diagnosa lainnya dan dapat membuat potongan koronal, sagital, aksial dan oblik, sehingga anatomi 
dan patologi jaringan tubuh dapat dievaluasi secara detail [2]

Penggunaan parameter-parameter dan sequence yang tepat dapat mempengaruhi kualitas citra MRI, Penggunaan parameter tersebut di antaranya terkait dengan densitas proton, voxel volume, TR (Time Repetition) yaitu interval waktu antara pulsa RF awal dengan RF kedua, TE (Time Echo) yaitu waktu untuk echo (mencatat sinyal), sudut balik (flip angle), NEX (Number of Excitation) yaitu berapa kali data dicatat dalam K-space), rentang frekuensi (receive bandwidth) yaitu besar frekuensi dan koil receiver yaitu elemen pencatat sinyal [3]

Pada penelitian ini menggunakan pembobotan T2 dengan sequence Gradient Echo. Pembobotan T2 dilakukan untuk melihat adanya suatu patologis, di mana air akan nampak putih dan lemak berwarna hitam, sehingga mudah untuk dilakukan diagnosis. Sequence Gradient Echo merupakan kelas dari urutan pulsa terutama digunakan untuk scanning cepat untuk menunjukkan cairan sendi dengan cerah [4].

Penelitian ini mengoptimalkan nilai bandwidth dan Time Echo (TE) untuk menghasilkan citra yang berkualitas. Bandwidth (BW) merupakan rentang frekuensi yang terjadi pada sampling data pada objek yang discan. Semakin kecil bandwidth maka noise akan semakin kecil tetapi akan berpengaruh pada TE minimal yang dipilih.

Penelitian sebelumnya yang dilakukan oleh [5], yaitu dengan meningkatkan atau memperbesar nilai receive bandwidth (BW) akan mengurangi adanya artefak. Artefak merupakan gangguan pada gambar yang diidentifikasi bukan suatu anatomi pada tubuh.

Susceptibility Artifacts adalah artefak karena adanya bahan implan logam pada tubuh pasien dapat berakibat pada berubahnya bentuk organ, atau muculnya area hitam pada gambar, sedangkan Chemical Shift artifacts adalah artefak yang terjadi karena adanya perbedaan ikatan atom hidrogen pada jaringan (terutama jaringan lunak dan lemak) dan tergambar sebagai batas berwarna hitam pada sisi luar organ. Kedua artefak tersebut mengganggu diagnosis dan hasil citra yang tidak optimal dan dapat dikurangi dengan mengoptimalkan pengaturan nilai BW dan TE [4].

\section{Metode}

Penelitian ini dilaksanakan di Instalasi Rumah Sakit Umum Haji Surabaya dengan menggunakan pesawat MRI Siemens terhadap empat pasien dengan kisaran usia antara 22-60 tahun, dengan 4 pasien patologis. Sampel penelitian merupakan scanning pasien dengan pembobotan T2 Medic Axial MRI Shoulder, dengan menggunakan sequence Gradient Echo (GRE) dan masing - masing sampel diberikan variasi TE $16 \mathrm{~ms}, 20 \mathrm{~ms}$ dan BW $170 \mathrm{~Hz} / \mathrm{Px}, 190 \mathrm{~Hz} / \mathrm{Px}$ dan $210 \mathrm{~Hz} / \mathrm{Px}$ dengan variabel terkendali sebagai berikut; TR selama 700 $\mathrm{ms}$, FOV seluas $180 \times 180 \mathrm{~mm}$, Slice thickness sepanjang $4 \mathrm{~mm}$, Phase Encoding sebesar 256x256, NEX 1. Setiap scanning (pengambilan gambar) dalam satu variasi TE dan BW dihasilkan 19 gambar yang akan dipilih satu gambar terbaik yang menunjukkan jaringan-jaringan yang akan dianalisis besar sinyalnya. Jaringan-jaringan tersebut adalah Humeral Bone, Glenoid Labrum, Fluid, Fat dan dilakukan terhadap Artefak serta noise background. Jaringan dan artefak dianalisis besarnya sinyal dengan teknik Region of Interest (ROI), untuk lebih jelasnya dapat dilihat pada gambar 1.

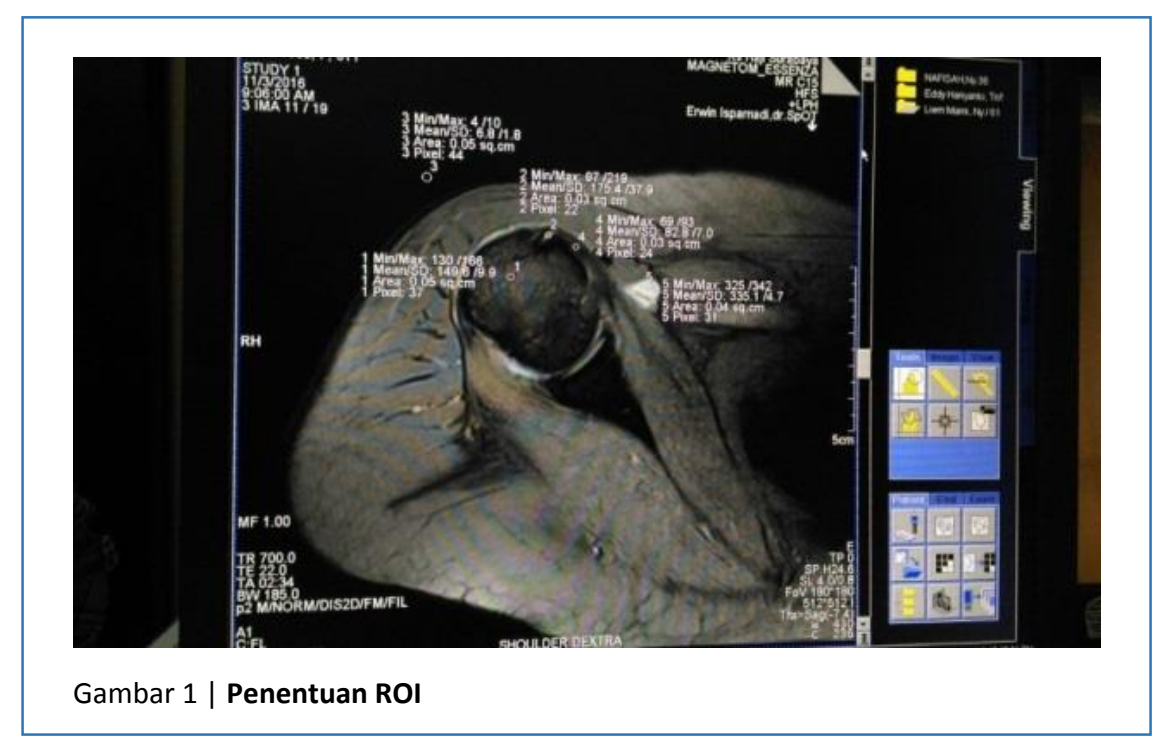


Teknik ROI digunakan para peneliti dalam pengambilan sinyal pada suatu daerah yang mendapatkan perhatian khusus sehingga area tersebut dapat mewakili jaringan yang ada (Russel A. Poldrack, 2007). Syarat melakukan ROI adalah dengan mengambil suatu daerah dengan luas penampang dengan standar deviasi yang sekecil mungkin. Daerah yang di-ROI harus mempunyai intensitas yang homogen [6].

Analisis data terbagi atas analisis non-statistik dan analisis statistik. Analisis non-statistik digunakan pada data kualitatif yaitu data yang tersusun bukan berdasarkan angka. Analisis non-statitsik ini biasanya diolah dan dianalisis berdasarkan subtansinya. Analisis statistik menggunakan data kuantitatif yaitu data yang berupa angka kemudian dilakukan uji statistik dengan menggunakan program SPSS.
ROI pada jaringan dilakukan dengan membuat area untuk mengetahui besar nilai mean pada satu gambar yang dipilih (Gambar 2 (a)). Mean tersebut menunjukkan besar sinyal (S) pada jaringan yang akan dianalisis untuk mengetahui nilai SNR dan CNR.

ROI pada background dilakukan dengan membuat area diluar jaringan, area tersebut dibuat lebih besar dari ROI jaringan, ROI background dipilih besar nilai standard deviation (SD) nya (Gambar 2(B)). Pengambilan ukuran lingkaran yang besar dikarenakan area background memiliki area yang cukup besar sehingga besar sinyalnya dapat mewakili area yang lain. Background tersebut merupakan noise $(\mathrm{N})$ yang akan dianalisis secara kuantitatif untuk mendapatkan SNR dan CNR.

ROI pada artefak dilakukan pada gambar yang memunculkan artefak. Artefak pada jaringan

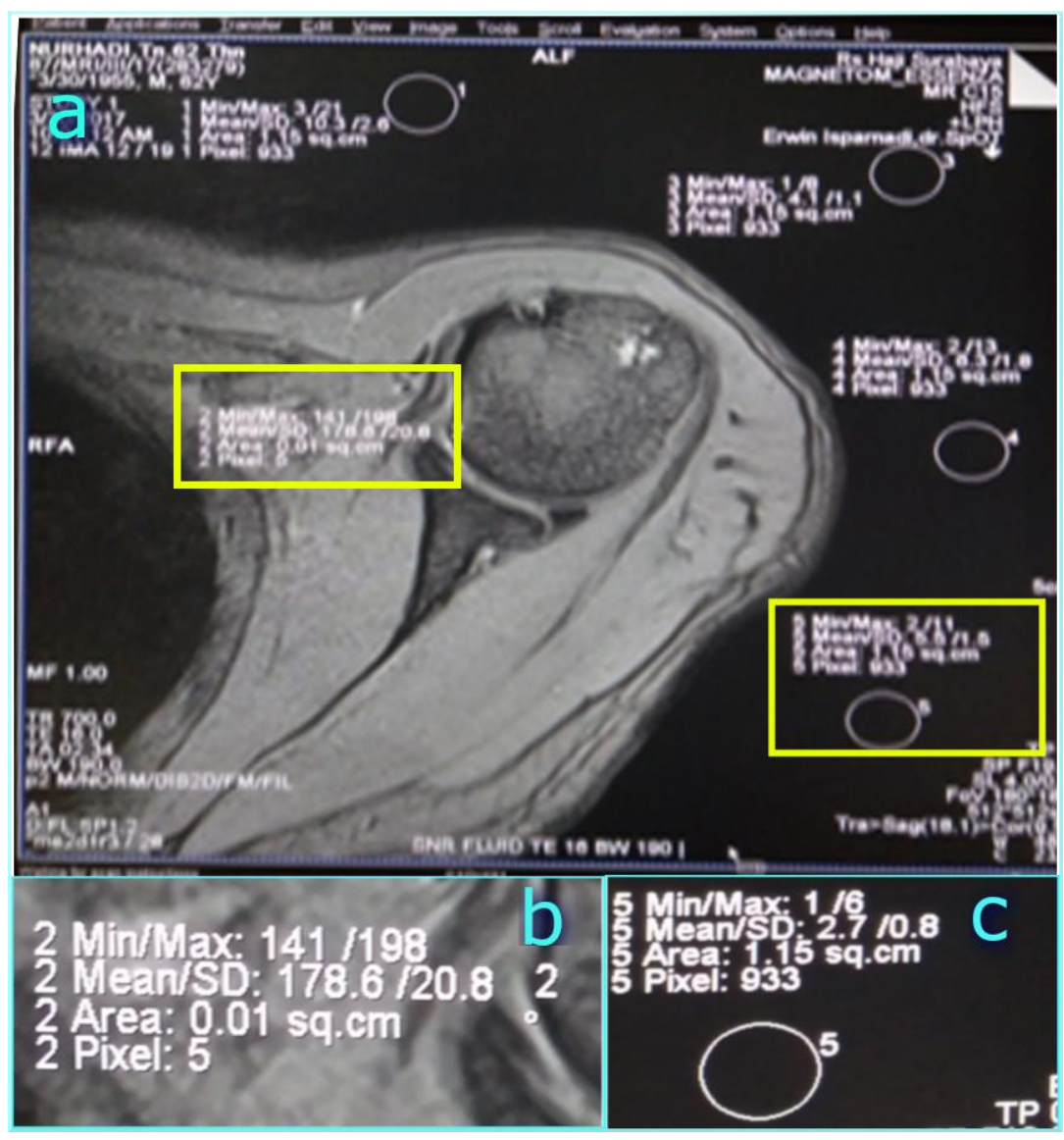

Gambar 2 | Hasil pengukuran ROI jaringan dan background

a. Citra MRI beserta satu area ROI pada jaringan (kotak kuning kiri) dan empat area ROI pada background. b. Nilai pengukuran ROI jaringan (hasil perbesaran kotak kuning kiri pada 2(a) ). c. Nilai salah satu ROI background (hasil perbesaran kotak kuning kanan pada 2(a)). 
terjadi karena tidak cukup waktu bagi jaringan pada saat pencatatan sinyal. Artefak terjadi karena banyak hal seperti kesalahan pada saat pasien bergerak, ataupun kesalahan bagi radiografer pada saat screening pasien, sehingga terdapat benda logam yang menempel pada tubuh pasien.

Berdasarkan Gambar 2 didapatkan nilai Min/ Max, Area dan Pixel. Nilai Min/Max merupakan besar intensitas sinyal dari nilai grayscale yang di angkakan oleh komputer dari terendah (minimum) sampai tertinggi (maksimum). Area merupakan luas daerah ROI pada jaringan yang akan di identifikasi dengan satuan sq.cm. Pixel merupakan banyaknya jumlah pixel, pada gambar tersebut didapatkan jumlah pixel sebanyak 933.

Analisis secara kuantitatif pada suatu gambar dengan variasi TE dan BW dilakukan dengan teknik ROI pada setiap jaringan dan background yang akan dianalisis besar nilai sinyal (S) dan noise (N).

$$
\begin{gathered}
\text { Signal to Noise }=\frac{1}{\sqrt{B W}} \\
\text { SNR }=\frac{\text { Signal }(S)}{\text { Noise }(N)} \\
\text { CNR }=S N R(2)-S N R(1)
\end{gathered}
$$

\section{Hasil \& Pembahasan}

Telah diperoleh 1 citra yang terbaik dari 19 citra dengan kombinasi variasi TE dan BW, kemudian dilakukan analisis SNR dan CNR dengan mengambil nilai mean yang merupakan sinyal dari jaringan Humeral Bone, Glenoid Labrum, Fluid, Fat dan dilakukan pengambilan nilai SD yang merupakan noise terhadap background. Jaringan dan background dianalisis besarnya sinyal dengan teknik Region of Interest (ROI).

\section{Analisis Signal to Noise Ratio (SNR)}

Dari Gambar 3 dapat dilihat bahwa semakin besar nilai TE dan BW maka nilai SNR turun pada setiap jaringan yaitu fluid, Glenoid Labrum (GL), Humeral Bone (HB), dan Fat. Dari hasil data dan penelitian menunjukkan bahwa pengaruh variasi TE dan BW terhadap nilai SNR tidak stabil atau linier karena setiap variasi yang diberikan menghasilkan SNR tertentu. Pengaruh kedua variasi tersebut menghasilkan perubahan nilai SNR, hal ini dipengaruhi oleh struktur molekul atom hidrogen pada setiap jaringan, jika pada jaringan tersebut mempunyai atom hidrogen yang banyak maka

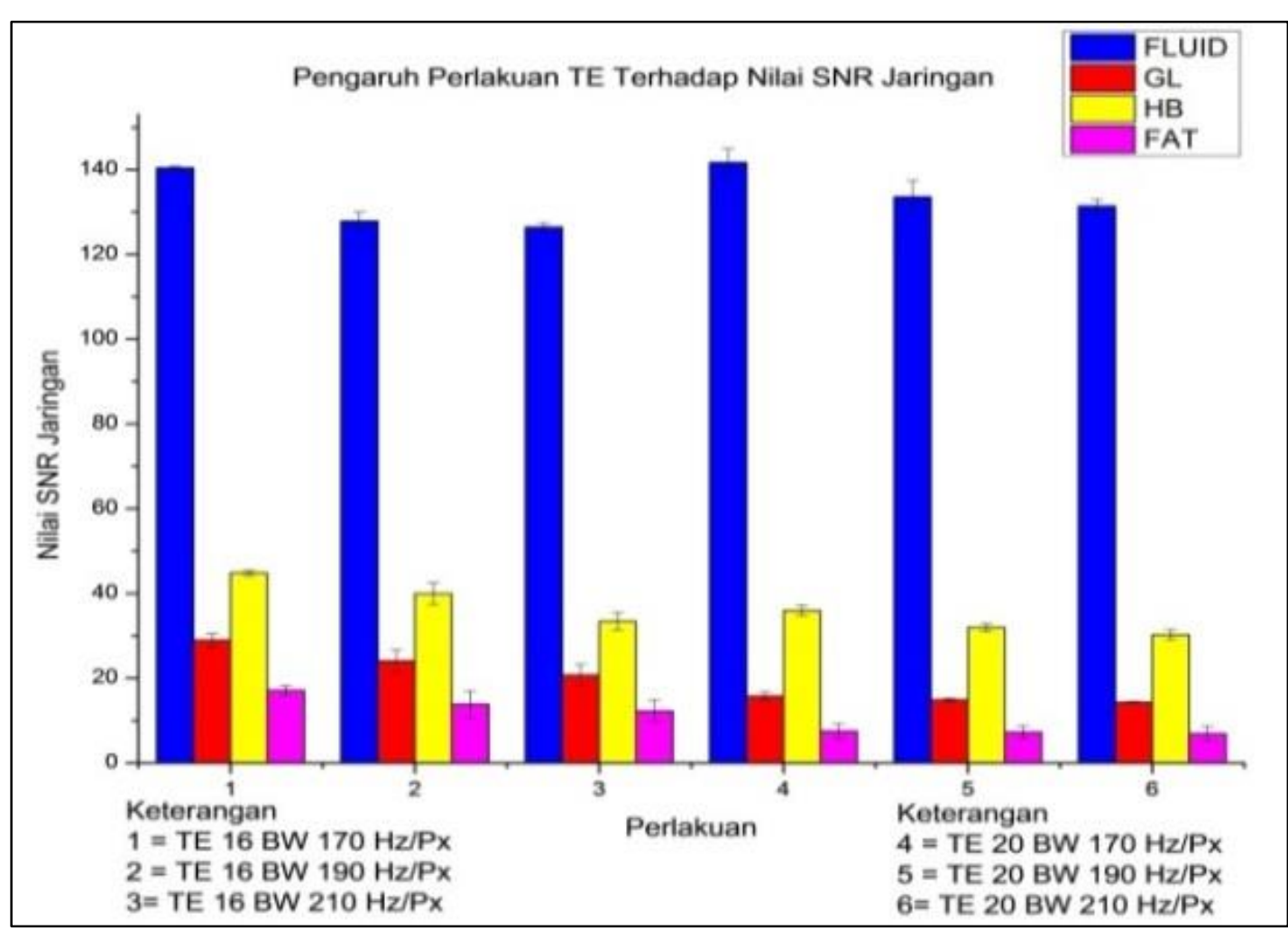

Gambar 3 | Grafik pengaruh variasi TE dan BW terhadap Nilai SNR 
jaringan tersebut mempunyai SNR yang tinggi. Faktor usia juga mempengaruhi hasil citra MRI karena komposisi atom hidrogen yang mulai berkurang pada setiap jaringan sehingga hasil SNR didapatkan rendah karena kurangnya atom hidrogen pada suatu jaringan.

\section{Analisis Contrast to Noise Ratio (CNR)}

Dari Gambar 4 terlihat bahwa semakin besar nilai TE dan BW, nilai CNR tiap 2 jaringan yang berdekatan menunjukkan penurunan. Jika TE diperbesar maka didapatkan CNR yang tinggi. Tetapi kenaikan nilai BW maka CNR mengalami penurunan.

Dari hasil data penelitian menunjukkan bahwa pengaruh variasi TE dan BW memberikan hasil yang linier terhadap nilai CNR. Pada jaringan tertentu dibutuhkan kontras yang tinggi untuk membedakan adanya patologis dengan jaringan disekelilingnya. Pada penelitian ini menjadi fokus utama adalah 2 jaringan yaitu Fluid dan Glenoid Labrum (GL), kedua jaringan tersebut terletak berdekatan sehingga dapat dihitung perbedaan kontrasnya, kebanyakan patologis didaerah bahu yang sering menjadi indikasi pemeriksaan MRI Shoulder terletak pada area GL. Pada kedua jaringan tersebut memiliki densitas yang berbeda, GL memiliki densitas proton yang kecil sehingga kurang rentan terhadap resonansi radio frekuensi sehingga memberikan signal yang rendah (hypointense). Sedangkan fluid peka terhadap resonansi radio frekuensi sehingga memberikan kontribusi besar pada citra (hyperintense). Perbandingan dari kedua jaringan tersebut dapat digunakan untuk patokan pengambilan nilai CNR yang optimal.

\section{Hubungan Pengaruh Variasi TE dan BW terhadap Nilai SNR dan CNR}

Berdasarkan nilai yang telah didapatkan dari hasil perhitungan secara kuantitatif dapat diketahui hubungan antara SNR dan CNR terhadap kedua variasi yang diberikan. Hubungan SNR dan CNR ditunjukkan pada Gambar 5.

Pada grafik diatas terdapat perbedaan hasil antara SNR dan CNR akibat adanya perubahan TE, dimana TE kecil akan menghasilkan SNR yang tinggi begitu sebaliknya, tetapi ketika TE semakin besar

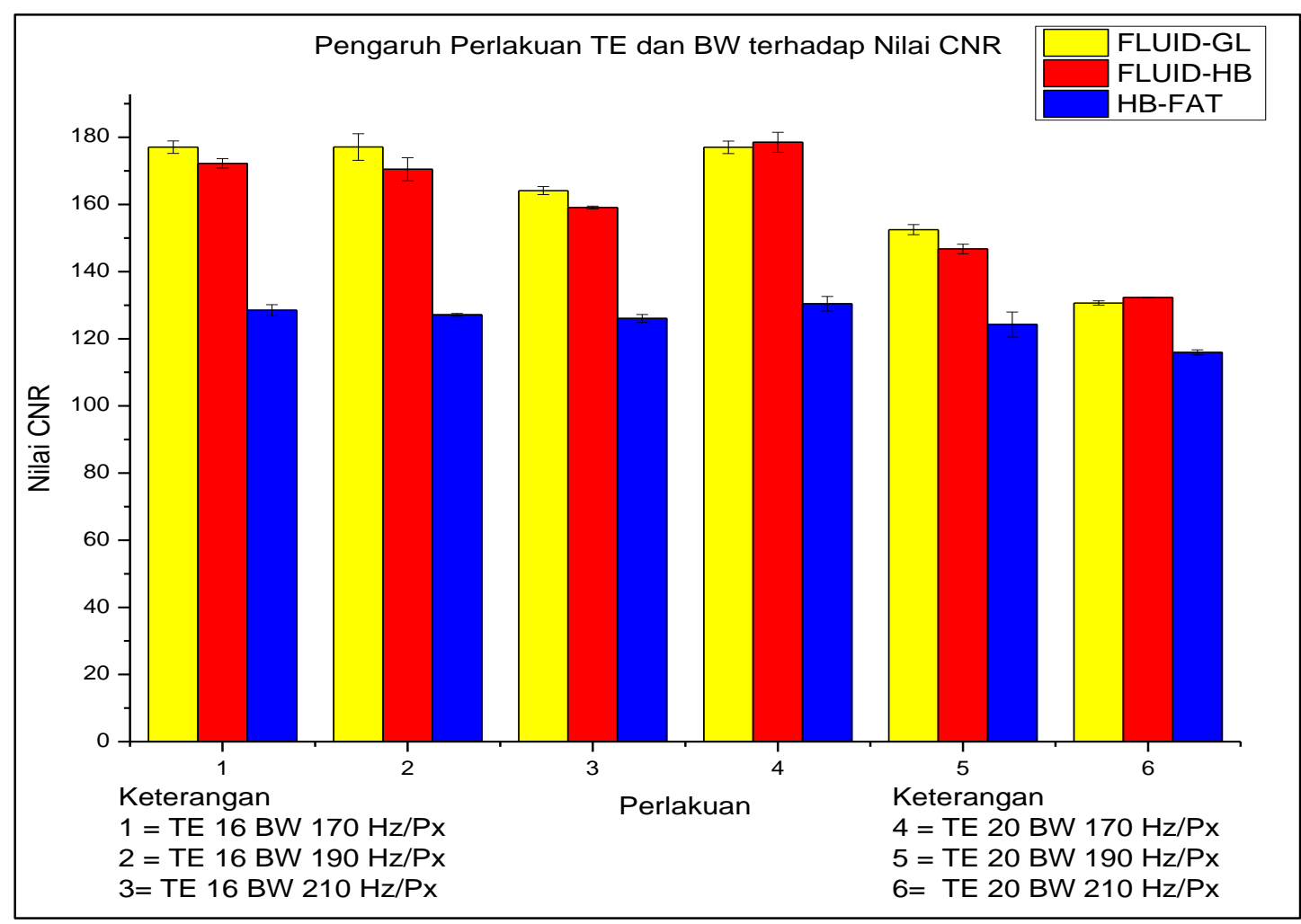

Gambar 4 | Grafik pengaruh variasi TE dan BW terhadap Nilai CNR 


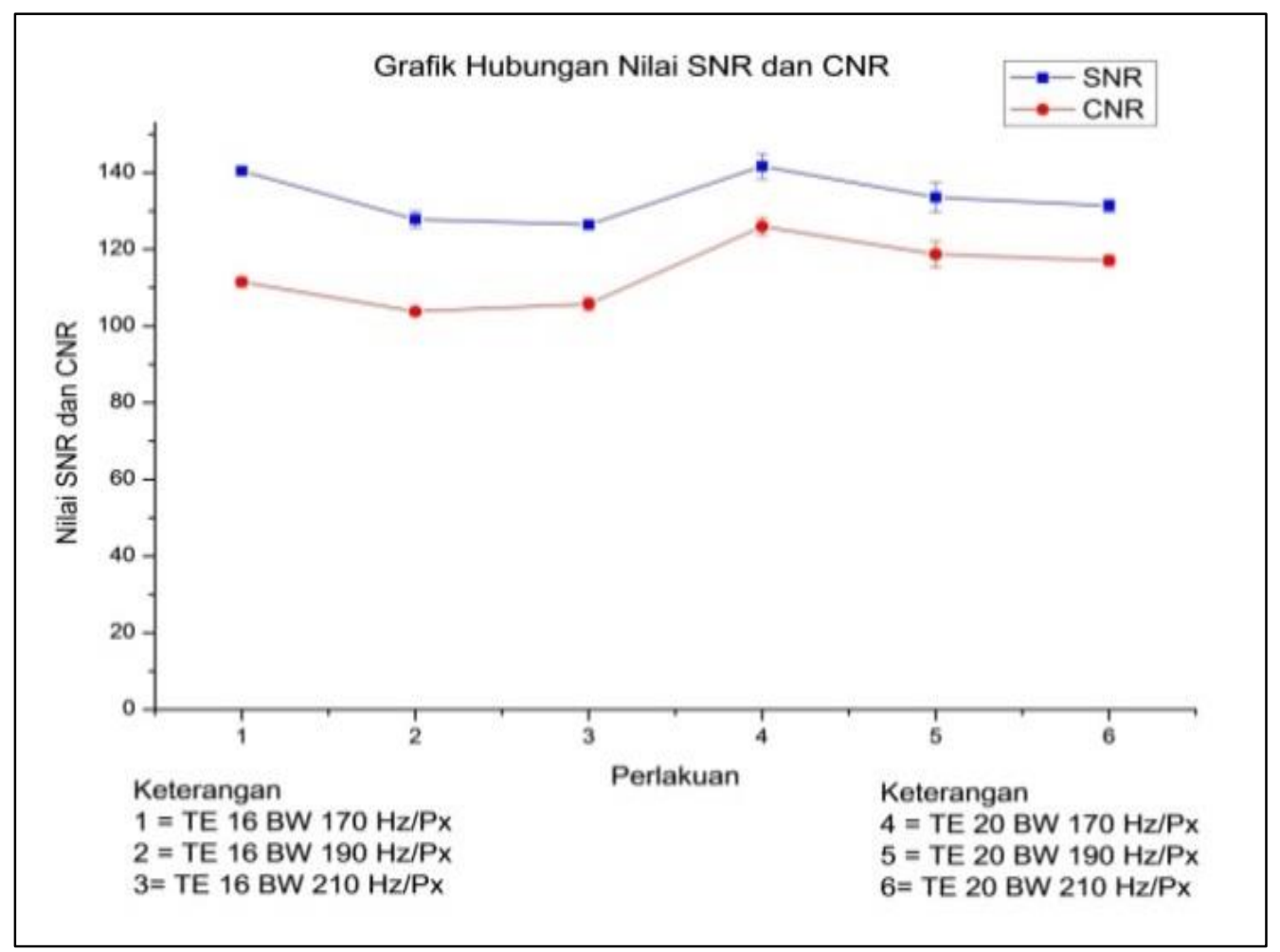

Gambar 5 | Grafik hubungan nilai SNR dan CNR
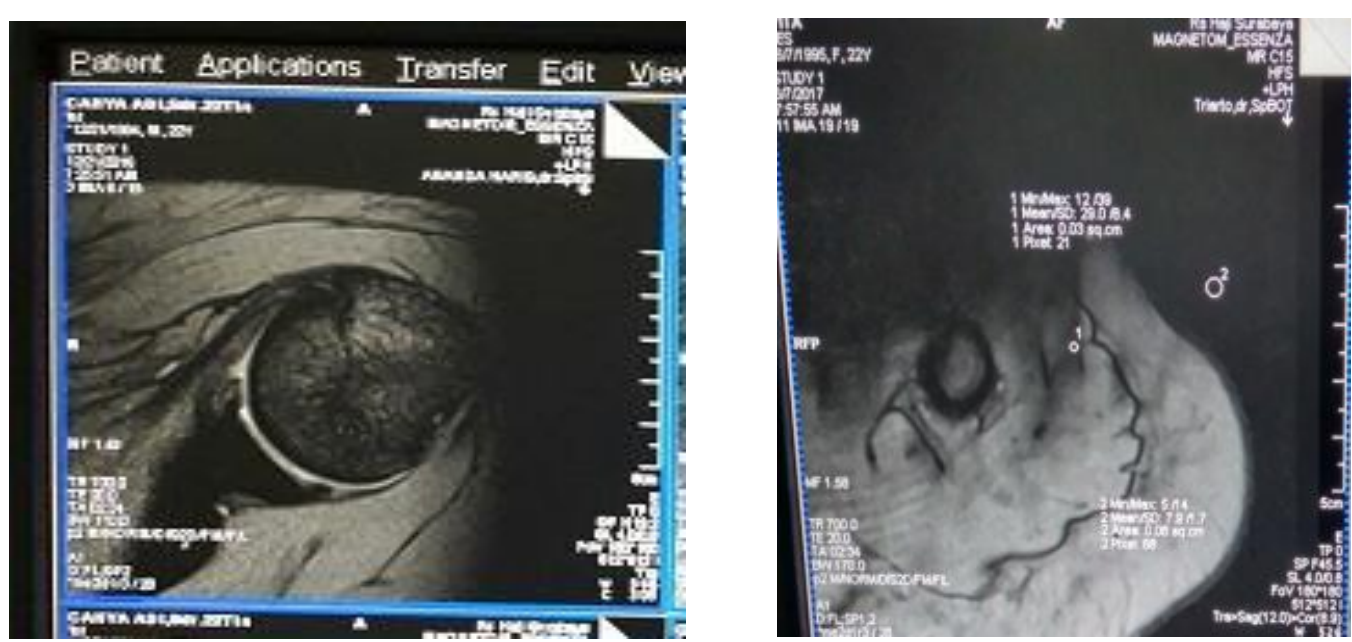

Gambar 6 | Pengaruh benda magnetik pada suatu citra

maka CNR semakin meningkat. Berbeda dengan bandwidth jika bandwidth semakin besar maka SNR semakin tinggi, jika nilai bandwidth diperbesar maka CNR sementara jika BW semakin besar maka CNR akan semakin menurun. Tetapi pada penelitian ini, tidak dapat dipisahkan antara variasi TE dan BW yang menghasilkan suatu nilai SNR maupun CNR. Sehingga pada penelitian ini dilihat pengaruh antara kombinasi variabel TE dan BW.

\section{Analisis Pengaruh Variasi TE dan BW terhadap Artefak}

Pada penelitian ini terdapat 2 artefak yang dianalisis, yaitu adanya artefak Chemical Shift dan susceptibility artifacts. Susceptibility Artifacts adalah artefak karena adanya bahan magnet atau 
implant logam pada tubuh pasien dapat berakibat pada munculnya area hitam pada organ sehingga dapat merusak suatu image, dapat dilihat pada Gambar 6.

Berdasarkan Gambar 7, pertama peneliti meninjau dari pengaruh variasi $\mathrm{BW}$, dimana BW semakin rendah maka rentang $\mathrm{BW}$ akan semakin pendek sehingga nilai pencatatan signalnya akan semakin sempit. Oleh sebab itu, tingkat grayscale yang dihasilkan akan semakin sempit sehingga artefak logam (Suceptibilty artifact) yang terdeteksi dengan sinyal hitam karena loss signal akan semakin sedikit. Ketika rentang frekuensinya (BW) lebar maka gray scale kehitaman tersebut akan di

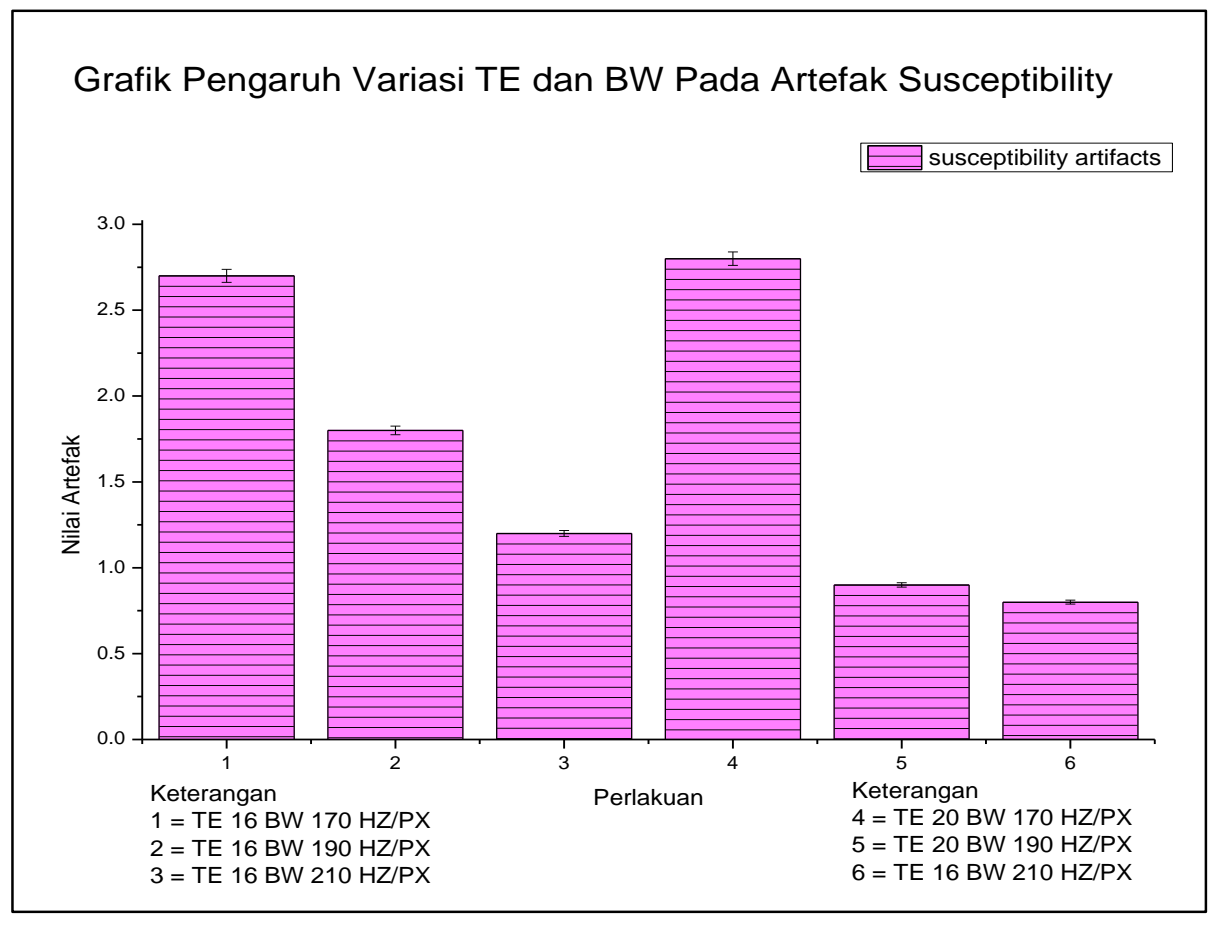

Grafik Pengaruh Perlakuan TE dan BW terhadap Sinyal yang terkena Artefak

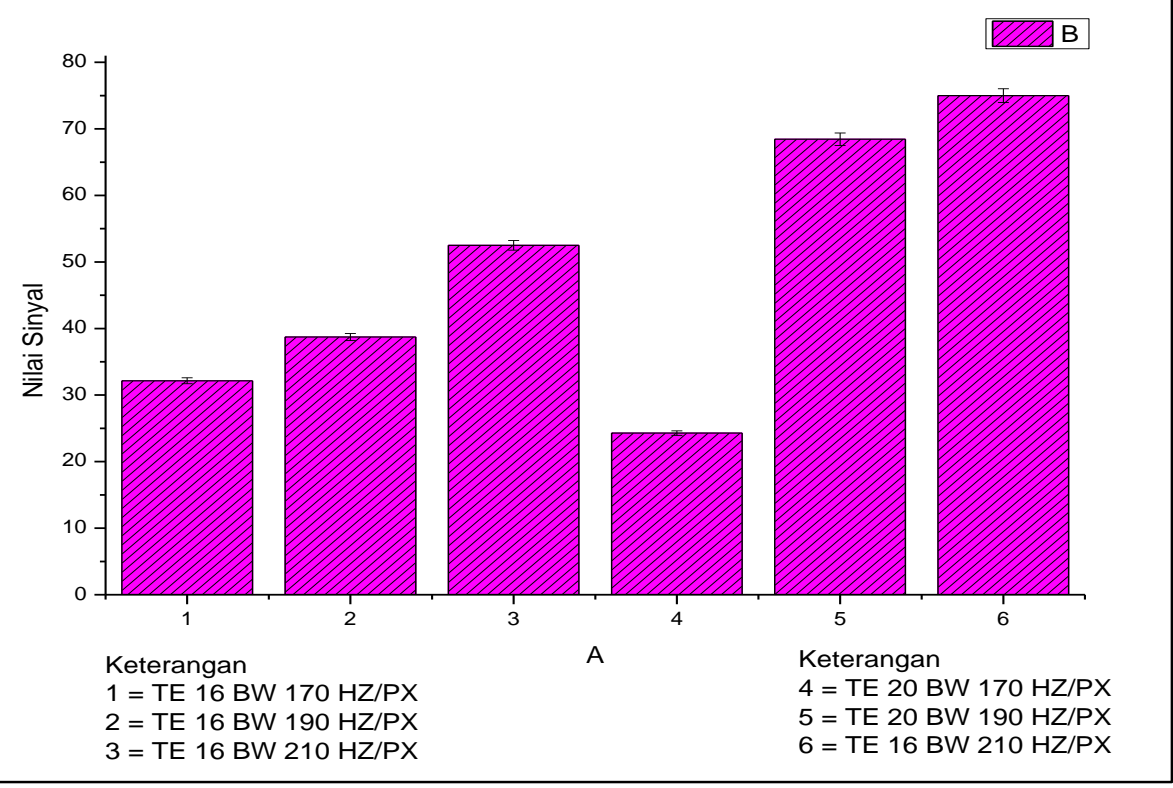

Gambar 7 | Grafik hubungan nilai SNR dan CNR 
Chemical Shift size $=\frac{\text { chemical shift for your magnet }(\delta)}{\text { bandwidth }}$

Persamaan 1 | Persamaan Chemical Shift Size sinyal maka akan semakin mengurangi artefak Suseptibility atau kehitaman akan semakin tinggi karena susceptibility tersebut akan semakin tercatat sinyalnya oleh pencatatan TE yang lebih sehingga semakin memperjelas kontras kehitaman karena logam tersebut.

Chemical Shift terjadi karena adanya perbedaan magnetic shielding pada jaringan (terutama jaringan lunak dan lemak). Tergambar sebagai batas berwarna hitam pada sisi luar organ. repetition (TR). Di mana semakin lama pencatatan
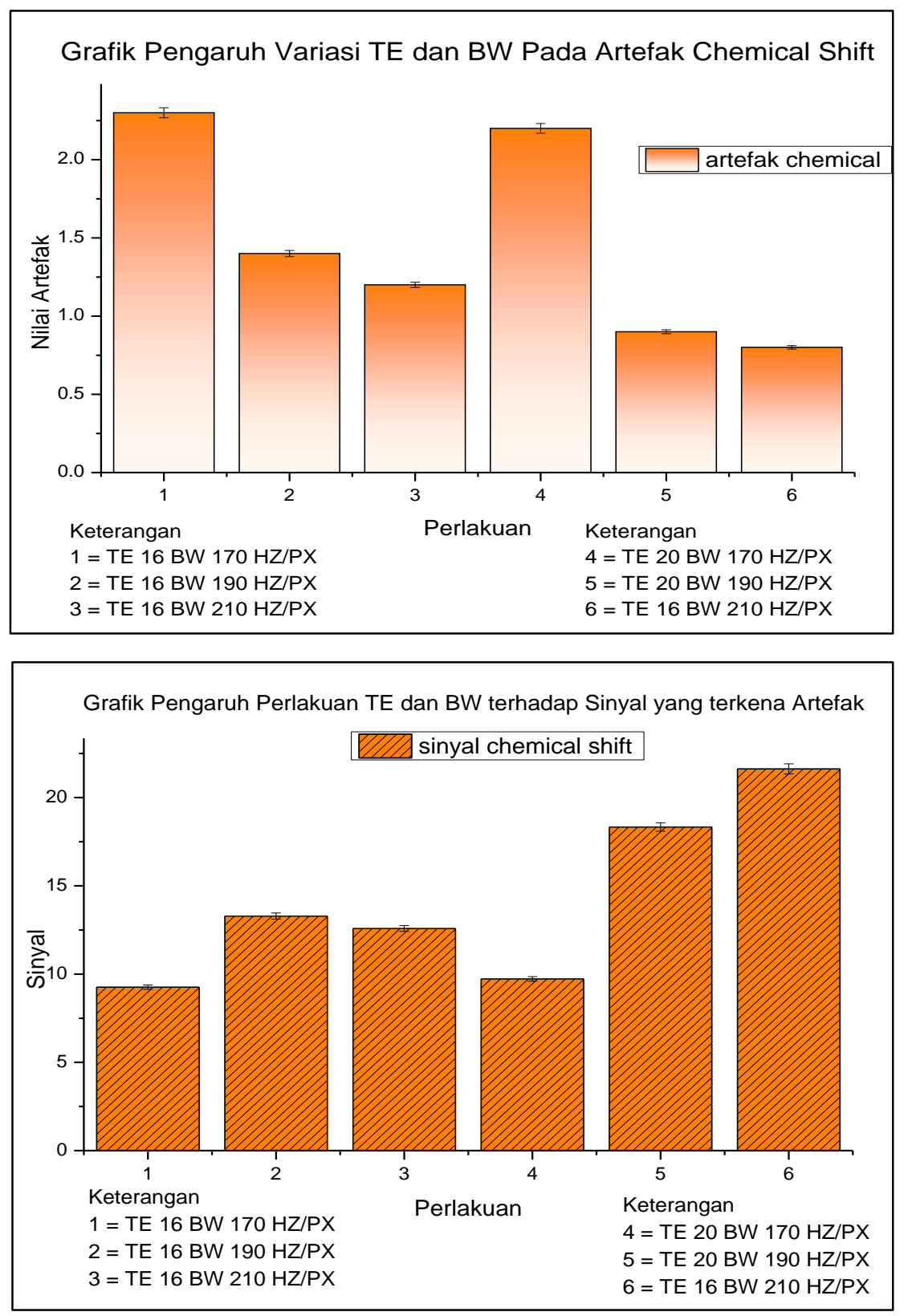

Gambar 8 | Pengaruh variasi TE dan BW terhadap sinyal Chemical Shift 


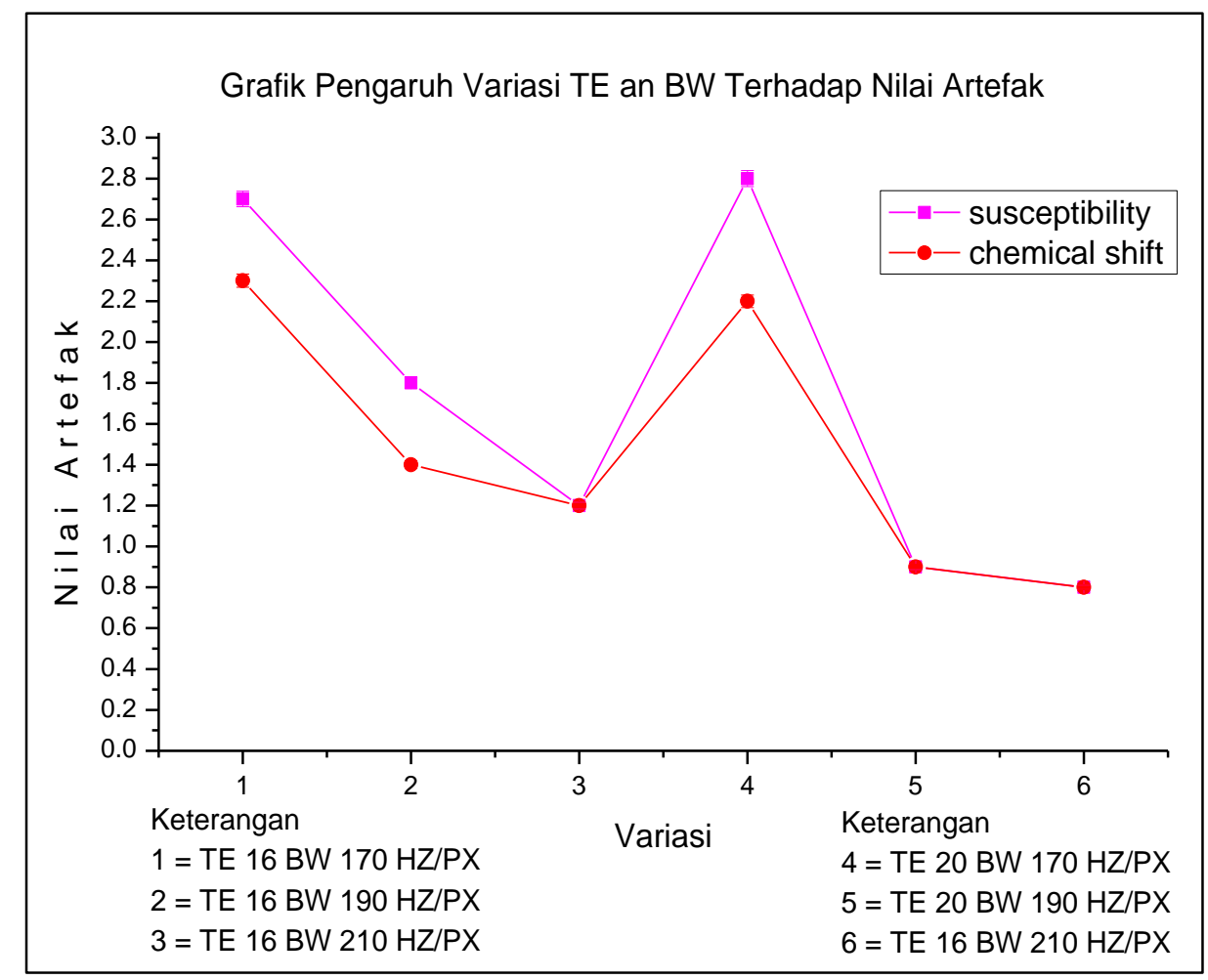

Gambar 9 | Grafik pengaruh variasi TE dan BW terhadap Nilai Artefak

Chemical Shift dapat terlihat pada penggunaan TE yang besar dan Bandwidth yang besar. Besarnya Chemical Shift dapat diperhitungkan dengan persamaan 1.

Berdasarkan Gambar 8, diketahui bahwa ketika nilai TE naik maka Chemical Shift akan cenderung semakin menurun, hal ini sesuai dengan teori bahwa adanya perbedaan ikatan atom hidrogen antara lemak dan jaringan lunak akan menyebabkan sinyal (kontras) menjadi tumpang tindih (overlap) sehingga memunculkan artefak. Kenaikan TE menghasilkan perbedaan precessional frekuensi antara fat dan water yang semakin lebar dan terlihat semakin jelas beda sinyalnya, sehingga analisis terhadap patologis menjadi akurat karena adanya artefak dapat dikurangi.

\section{Penentuan Nilai Optimal Variasi TE dan BW Terhadap Nilai Artefak}

Penentuan nilai optimal pada kedua variasi tersebut diperoleh dengan membuat grafik secara terpisah antara variabel TE dengan Artefak dan BW dengan Artefak (Gambar 9).
Grafik pada gambar 9 memperlihatkan bahwa nilai optimal yang menunjukkan succepbility artifact dan Chemical Shift artifact paling rendah pada TE 20 ms dengan kombinasi BW $210 \mathrm{~Hz} / \mathrm{Px}$. Pada nilai tersebut artefak semakin menurun, sehingga ketika semakin rendah nilai artefak, maka sinyal anatomi yang dinilai dapat dilihat dengan jelas yang terdapat pada suatu citra. Semakin rendah nilai artefak tersebut maka dokter dapat dengan mudah menilai patologis, sehingga tidak salah dalam menegakkan diagnosa.

\section{Penentuan Nilai Optimal Variasi TE dan BW terhadap Nilai CNR}

Berdasarkan Gambar 5 dan 9 dapat ditentukan nilai optimal untuk CNR dan (dua) artefak tersebut. Dimana pada gambar 5 yaitu grafik pengaruh antara TE dan BW terhadap nilai CNR diketahui bahwa pada variasi TE 20 ms dan BW $170 \mathrm{~Hz} / \mathrm{Px}$ terlihat adanya kenaikan kualitas kontras citra. Sedangkan pada gambar 9 yaitu grafik pengaruh antara TE dan BW terhadap artefak diketahui bahwa pada variasi TE 20 ms dan BW $210 \mathrm{~Hz} / \mathrm{Px}$ menunjukkan penurunan nilai artefak. Kemudian 


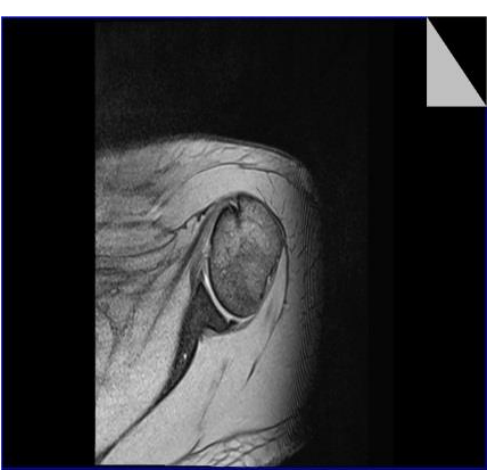

TE 16 BW 170 HZ/PX

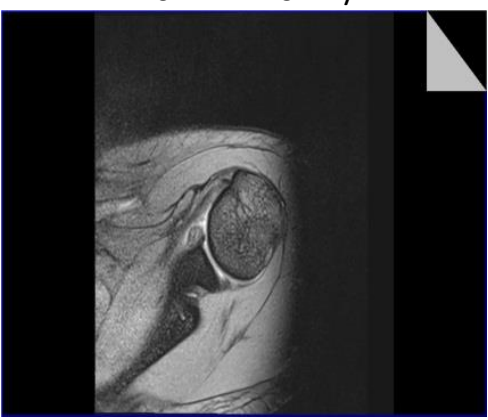

TE 20 BW 170 HZ/PX

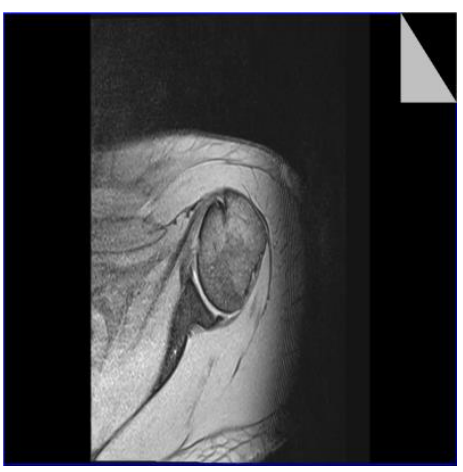

TE 16 BW 190 HZ/PX

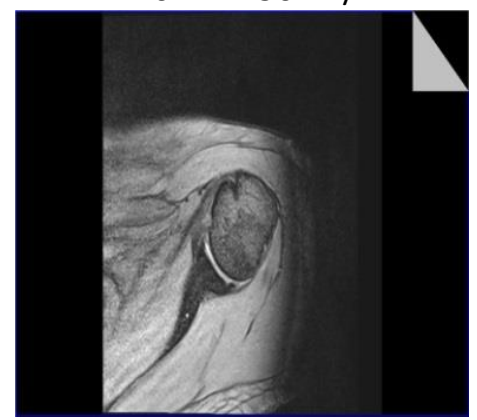

TE 20 BW 190 HZ/PX

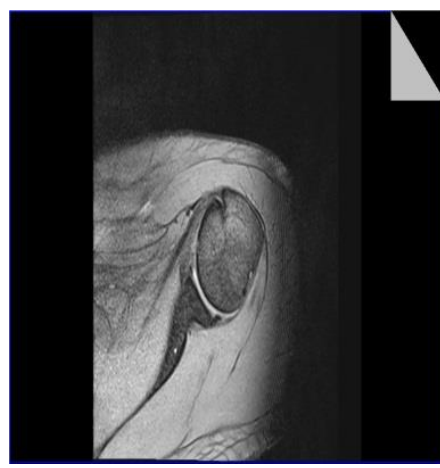

TE 16 BW $210 \mathrm{HZ} / \mathrm{PX}$

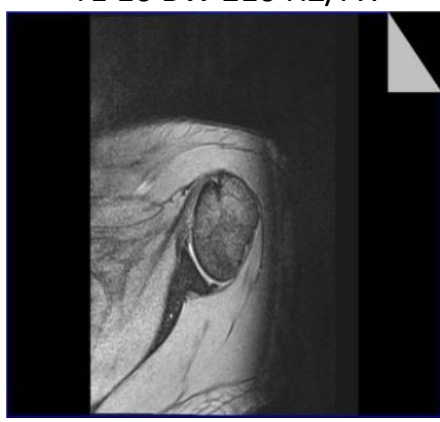

TE 20 BW $210 \mathrm{HZ} / \mathrm{PX}$

Gambar 10 | Foto hasil pemeriksaan dengan variasi TE dan BW (terlihat adanya artifak dikarenakan benda logam)

pengaruh TE dan BW terhadap CNR dan Artefak dianalisis menggunakan uji statistik untuk menentukan beda signifkan. Diketahui bahwa pada uji statistik menggunakan uji multivariat pada jaringan fluid - humeral bone dihasilkan nilai sig 0.319 sehingga tidak terdapat beda bermakna. Oleh karena itu peneliti, mengkorelasikan hasil data lapangan dan uji statistik dengan teori yang ada sebelumnya diapatkan pada TE 20 ms dan BW $210 \mathrm{~Hz} /$ Px dapat menurunkan adanya artefak yang disebabkan oleh Chemical Shift dan susceptibility (gambar 10).

\section{Kesimpulan}

Berdasarkan penelitian yang telah dilakukan, maka dapat disimpulkan bahwa variasi Time Echo dan bandwidth berpengaruh signifikan terhadap nilai SNR dan CNR pada hasil citra T2 Axial Gradient Echo MRI Shoulder. Pengaruh kedua variasi tersebut adalah semakin kecil nilai TE dan BW didapatkan SNR yang meningkat. Jika TE diperbesar maka didapatkan CNR yang meningkat.

Kualitas citra optimal yang dapat menghasilkan keadaan patologis ditentukan dengan meningkat- nya nilai CNR dan nilai artefak yang menurun Sehingga Pada penelitian ini kombinasi antara 2 variabel tersebut dapat menentukan citra optimal pada TE $20 \mathrm{~ms}$ dan BW $210 \mathrm{~Hz} / \mathrm{Px}$.

\section{Bibliografi}

1. D. E. G. A. Rani, "Adln - perpustakaan universitas airlangga," 2016.

2. A. Tanjung, A. Prastowo, and W. Setiabudi, "Korelasi Nilai Time Repetition (TR) dan Time Echo (TE) Terhadap Signal To Noise Ratio (SNR) Pada Citra MRI," vol. 16, no. 4, pp. 103-110, 2013.

3. C. Wesbrook, Handbook MRI Technique Fourth Edition. This edition first published 2014 @ 2014 by John Wiley \& Sons, Ltd., 2014.

4. M. Brown and R. Semelka, MRI Basic Principles and Aplications, 3rd ed. 2003.

5. J. Graessner, "Bandwidth in MRI?," Siemens.Com, vol. 2, pp. 3-8, 2013.

6. Fatimah dkk. 2015. Optimisasi Field Of View (FOV) Terhadap Kualitas Citra Pada T2WI FSE Mri Lumbal Sagital. Semarang: Berkala Fisika JImeD, Vol. 1, N0. 1, Undip Forshult, 